\title{
The natural infection of Melanoides tuberculata (Müller, 1774) (Mollusca: Gastropoda) by Centrocestus formosanus (Nishigori, 1924) (Platyhelminthes: Trematoda) in Paranoá lake, Brasília, Brazil
}

\author{
Paula-Andrade, C. ${ }^{a}$, Pinto, HA. ${ }^{b}$, Coscarelli D. ${ }^{a}$, Vidigal, THDA. ${ }^{a}$ and Melo, AL. ${ }^{b *}$ \\ a'Laboratório de Malacologia e Sistemática Molecular, Departamento de Zoologia, Instituto de Ciências Biológicas, \\ Universidade Federal de Minas Gerais - UFMG, CEP 31270-901, Belo Horizonte, MG, Brazil

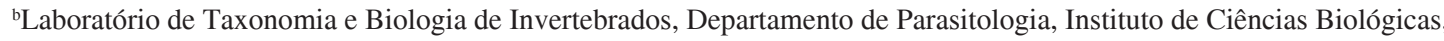 \\ Universidade Federal de Minas Gerais - UFMG, CEP 31270-901, Belo Horizonte, MG, Brazil \\ *e-mail: aldemelo@icb.ufmg.br \\ Received May 23, 2011 - Accepted August 23, 2011 - Distributed May 31, 2012
}

\begin{abstract}
Melanoides tuberculata (Müller, 1774), a freshwater snail first described in Asia, belongs to the Thiaridae (Caenogastropoda: Cerithioidea), and it is considered an invasive species with features of an r-strategist. Those features have allowed this thiarid to rapidly reach a high population density in its new habitat. It is an iteroparous organism that protects its young, is capable of parthenogenesis, displays phenotypic and genetic variability, and possesses ecological plasticity. M. tuberculata can be found in the Old and New World and has been spreading in the Caribbean area and in North and South America (Quintana et al., 2001-2002; Letelier et al., 2007; Pointier et al., 2011; Peso et al., 2011). In Brazil, the first introduction of this snail probably occurred in 1967 (Vaz et al., 1986) and, since then, it has spread to several states (Thiengo et al., 2007; Santos and Eskinazi-Sant'Anna, 2010). Its introduction can directly alter biological communities through competitive interactions with endemic snails, which can lead to the decline or extinction of local species. In fact, $M$. tuberculata have already been successful in eliminating or reducing populations of schistosome-transmitting snails in some localities. Besides that, thiarids are intermediate hosts of helminthes, which infect mammals, birds and fishes, including parasites that are of medical and veterinary importance (Mitchell et al., 2005; Pointier et al., 2011; Pinto and Melo, 2011). Among these parasites, M. tuberculata can harbour larvae of Clonorchis sinensis (Cobbold, 1875) and Paragonimus westermani (Kerbert, 1878). These are two trematodes that affect human beings, mainly in Asia. Recently, this thiarid was recorded in Al-Abtal village (North Sinai) as being a natural intermediate host of Angiostrongylus cantonensis (Chen, 1935), which is a nematode that causes infectious eosinophilic meningitis (Ibrahim, 2007).

Since the first recording of M. tuberculata in Brazil, its natural infection by trematodes was reported in 2001 thirtyfour years later in the state of Rio de Janeiro, and subsequently other findings were registered from the same state (Thiengo et al., 2007). Recently, Pinto and Melo (2010a, b) reported larvae from the Pleurolophocercous and Megalurous groups in M. tuberculata in the state of Minas Gerais; these larvae were identified as Centrocestus formosanus
\end{abstract}

(Nishigori, 1924) and Philophthalmus gralli Mathis and Leger, 1910, respectively.

The present note reports the natural infection of M. tuberculata by C. formosanus in Brazil's Federal Capital, Brasília. The material studied consisted of 48 snails collected with a scoop net and long forceps at the margins of Paranoá Lake $\left(15^{\circ} 51,608^{\prime} \mathrm{S}\right.$ and $\left.47^{\circ} 52,346^{\prime} \mathrm{W}\right)$ in March and October of 2007. This is an artificial reservoir that was constructed in 1959 to provide recreational activities in Brasília (Monteiro and Dias, 1980; PadovesiFonseca et al., 2009). All procedures, such as collecting thiarids, detecting larval trematode, the experimental infection of fish Poecilia reticulata (Peters, 1859), the infection of mice (AKR/J strain), metacercariae recovery, and the fixation and colouration of the obtained parasites were performed as described by Pinto and Melo (2010a). Trematode larvae were found in 16 snails (33\%) and were preliminarily identified as Pleurolophocercous cercariae. Infection of fifteen fish with these cercariae resulted in the formation of metacercariae in the gills. After recovering the metacercariae, they were administered orally to two male adult mice (fifty metacercariae/mouse). Twenty-five adult parasites were recovered from the small intestine of the mice 15 days after infection. The morphological analysis of the developmental stages (cercariae, metacercariae and adult parasites) was performed as described in Pinto and Melo (2010a); this confirmed the presence of $C$. formosanus in M. tuberculata from Paranoá Lake. The studied snails and adult trematodes obtained in this study were deposited respectively in the collections of the Departments of Zoology (2688-2689 and 2692-2696) and Parasitology (5923a-d) at the Universidade Federal de Minas Gerais.

Although Monteiro and Dias (1980) reported several snails species from lake Paranoá basin, $M$. tuberculata was first registered in this Lake by Vaz et al. (1986) and later by Martins-Silva and Barros (2001). However, only now, thirty years after the first reporting, their natural infection by trematodes has been investigated. C. formosanus is a trematode that originated from Asia, and there are several reports of its introduction and the involvement of $M$. tuberculata in its transmission in the Americas (Cortés et al., 2010; Pinto and Melo, 2010a; Pointier et al., 2011). Specimens of this thiarid were reported in several Brazilian states, presenting high densities in eutrophic and 
impacted environments such as Paranoá Lake (RochaMiranda and Martins-Silva, 2006), which may favour the maintenance of the life cycle of $C$. formosanus in these localities. This parasite requires a wide variety of fishes as a second intermediate host, and piscivorous birds and mammals are its definitive hosts. C. formosanus is responsible for a human food-borne intestinal infection that is acquired by the ingestion of raw or undercooked freshwater fish (Scholz and Salgado-Maldonado, 2000).

In addition to the diverse ecological problems, $M$. tuberculata and C. formosanus also generate economic impacts in some localities. C. formosanus is called the "gill trematode" because it affects the health of fishes, causing losses estimated to be $\$ 3.5$ million (USD) annually. Lawprotected aquatic birds in United States can carry this parasite, and thus, research efforts have been directed to find a means to control the snails that serve as the vectors for the trematode (Mitchell et al., 2005). However, the extension of the damage caused in Brazilian fauna is still unknown. The invasive snail hosts can establish new sites of parasite transmission in parasite-free areas such as Paranoa Lake, where there are species that can act as intermediate and definitive hosts for the parasite (Padovesi-Fonseca et al., 2009; Pointier et al., 2011). Since M. tuberculata was recorded in Brazil, few studies have assessed its geographical distribution, infection status and ecology, which all are considered important topics in biological invasion studies (Thiengo et al., 2007; Santos and Eskinazi-Sant'Anna, 2010). This note is the second reporting of $M$. tuberculata as an intermediate host of this heterophyid in Brazil.

\section{References}

CORTÉS, DA., DOLZ, G., ZÚÑIGA, JJR., ROCHA, AEJ. and ALAN, DL. 2010. Centrocestus formosanus (Opisthorchiida: Heterophyidae) como causa de muerte de alevines de tilapia gris Oreochromis niloticus (Perciforme: Cichlidae) en el Pacífico seco de Costa Rica. Revista de Biologia Tropical, vol. 58, no. 4, p. 1453-1465. PMid:21250483.

IBRAHIM, MM., 2007. Prevalence and intensity of Angiostrongylus cantonensis in freshwater snails in relation to some ecological and biological factors. Parasite, vol. 14, no. 1, p. 61-70. PMid:17432058.

LETELIER, S., RAMOS, AML. and HUAQUÍN, LGM., 2007. Moluscos dulceacuícolas exóticos en Chile. Revista Mexicana de Biodiversidad, vol. 78, p. 9-13.

MARTINS-SILVA, MJ. and BARROS, M., 2001. Occurrence and distribution of fresh-water molluscs in the Riacho Fundo Creek Basin, Brasilia, Brazil. Revista de Biologia Tropical, vol. 49, no. 3, p. 865-870. PMid:12189816.

MITCHELL, AJ., OVERSTREET, RM., GOODWIN, AE. and BRANDT, TM., 2005. Spread of an exotic fish-gill trematode: a far-reaching and complex problem. Fisheries, vol. 30, no. 8, p. 11-16. http://dx.doi.org/10.1577/1548-8446(2005)30[11:SOAEFT]2.0.CO;2

MONTEIRO, W. and DIAS, MLF., 1980. Distribuição de moluscos pulmonados aquáticos e identificação dos planorbídeos da Bacia do Lago Paranoá, Brasília (Mollusca: Gastropoda). Revista Brasileira de Biologia, vol. 40, no. 1, p. 67-74.
PADOVESI-FONSECA, C., PHILOMENO, MG. and ANDREONIBATISTA, C., 2009. Limnological features after a flushing event in Paranoá Reservoir, central Brazil. Acta Limnologica Brasiliensia, vol. 21, no. 3, p. 277-285.

PESO, JG., PÉREZ, DC. and VOGLER, RE., 2011. The invasive snail Melanoides tuberculata in Argentina and Paraguay. Limnologica, vol. 41, no. 4, p. 281-284 http://dx.doi.org/10.1016/j. limno.2010.12.001

PINTO, HA. and MELO, AL., 2010a. Melanoides tuberculata (Mollusca: Thiaridae) as an intermediate host of Centrocestus formosanus (Trematoda: Heterophyidae) in Brazil. Revista do Instituto de Medicina Tropical de São Paulo, vol. 52, no. 4, p. 207-210. http://dx.doi.org/10.1590/S0036-46652010000400008

-, 2010b. Melanoides tuberculata as intermediate host of Philophthalmus gralli in Brazil. Revista do Instituto de Medicina Tropical de São Paulo, vol. 52, no. 6, p. 323-327. http://dx.doi. org/10.1590/S0036-46652010000600007

-, 2011. A checklist of trematodes (Platyhelminthes) transmitted by Melanoides tuberculata (Mollusca: Thiaridae). Zootaxa, vol. 2799, p. 15-28.

POINTIER, JP., DAVID, P. and JARNE, P., 2011. The biological control of the snail hosts of schistosomes: the role of competitor snails and biological invasions In TOLEDO, R. and FRIED, B. (Eds.). Biomphalaria snails and larval trematodes. New York; London: Springer. p. 215-238.

QUINTANA, MG., PESO, JG. and PÉREZ, DC., 2001-2002. Alteración del régimen fluvial y reemplazo de especies de Thiaridae en el embalse de Yacyretá (Argentina-Paraguay). Journal of Medical and Applied Malacology, vol. 11, p. 107-112.

ROCHA-MIRANDA, F. and MARTINS-SILVA, MJ., 2006. First record of the invasive snail Melanoides tuberculatus (Gastropoda: Prosobranchia: Thiaridae) in the Paranã River basin, GO, Brazil. Brazilian Journal of Biology, vol. 66, no. 4, p. 1109-1115. http:// dx.doi.org/10.1590/S1519-69842006000600018

SANTOS, CM. and ESKINAZI-SANT'ANNA, EM., 2010. The introduced snail Melanoides tuberculatus (Muller, 1774) (Mollusca: Thiaridae) in aquatic ecosystems of the Brazilian Semiarid Northeast (Piranhas-Assu River basin, State of Rio Grande do Norte). Brazilian Journal of Biology, vol. 70, no. 1, p. 1-7. http://dx.doi.org/10.1590/S1519-69842010000100003

SCHOLZ, T. and SALGADO-MALDONADO, G., 2000. The introduction and dispersal of Centrocestus formosanus (Nishigori, 1924) (Digenea: Heterophyidae) in Mexico: a review. American Midland Naturalist, vol. 143, no. 1, p. 185-200. http://dx.doi. org/10.1674/0003-0031(2000)143[0185:TIADOC]2.0.CO;2

THIENGO, SC., FERNANDEZ, MA., MATTOS, AC. and BARBOSA, AF., 2007. Dispersão do molusco introduzido Melanoides tuberculatus (Müller, 1774) (Gastropoda: Thiaridae) no Brasil. In SANTOS, SB., PIMENTA, AD., THIENGO, SC., FERNANDEZ, MA. and ABSALÃO, RS., (Orgs.). Tópicos em Malacologia - Ecos do XVIII Ebram. Rio de Janeiro: Editora Sociedade Brasileira de Malacologia. p. 101-106.

VAZ, JF., TELES, HMS., CORREA, MA. and LEITE, SPS., 1986 Ocorrência no Brasil de Thiara (Melanoides) tuberculata (O.F. Müller, 1774) (Gastropoda, Prosobranchia), primeiro hospedeiro intermediário de Clonorchis sinensis. Revista de Saúde Pública, vol. 20, no. 4, p. 318-322. PMid:3554478. 